\title{
Evaluation of Mastitis Related Measures \& Their Applications to Classify Buffalo Milk in Chitwan, Nepal
}

\author{
Ishwari Prasad Dhakal ${ }^{1}$ and Hajime Nagahata ${ }^{2}$ \\ 1. Agriculture and Forestry University (AFU), Rampur, Chitwan, Nepal \\ 2. Rakuno Gakuen University, Ebetsu, Hokkaido 069-8501, Japan
}

\begin{abstract}
A study was performed to evaluate the epidemiological aspects of buffalo mastitis in the District Chitwan, Nepal for characterizing the California mastitis test (CMT), somatic cell count (SCC), electrical conductivity (EC) values and bacteriological analysis for defining buffalo milk. The CMT was performed by mixing equal volume of milk and 3\% sodium lauryl sulphate. The SCC was determined by staining milk film with New Man's Lampert Stain and EC values were measured by manual digital mastitis detector and expressed as $\mathrm{mS} / \mathrm{cm}$. Bacteriological analysis was done on the basis of Gram's stain, morphological findings, colony characteristics and biochemical tests. The maximum number (16\%) of clinical cases of mastitis was observed in the month of July and lowest in the month of April (1.6\%). When the temperature and humidity increased, it indicates that there is need for better care of lactating buffaloes during this month. On a quarter basis, $16 \%$ of the foremilk samples in buffaloes were diagnosed as having subclinical mastitis and $11 \%$ were diagnosed as having clinical mastitis. The results of CMT scores and SCC showed the evidence that subclinical and clinical mastitic milk was having CMT positive scores $(+1 \sim+3)$ with $\geq 200 \times 10^{3}$ cells $/ \mathrm{mL}$. The mean $\mathrm{pH}$ of clinically normal buffalo milk was 6.75 (range 6.39 to 7.08) and subclinical mastitic and clinical mastitic milk was 6.85 (range 6.37 to 7.10) and 6.88 (range 6.41 to 7.20), respectively. Analysis of EC value in the milk revealed the presence of mastitis in buffaloes and the cut-off values was $3.7 \mathrm{mS} / \mathrm{cm}$. The coagulase negative Staphylococcus (CNS), such as S. albus and S. epidermidis were the predominant organisms associated with subclinical mastitis, and CNS and coliforms in clinical mastitis. This information suggests that environmental mastitis was prevalent in buffaloes of Chitwan District. In this study, $9.5 \%$ of the quarters were having bacterial count (BC) more than $250 \mathrm{cfu} / \mathrm{mL}$. The proposed criteria for normal milk are absence of clinical signs, CMT negative, SCC $<200 \times$ $10^{3}$ cells $/ \mathrm{mL}, \mathrm{EC}<3.7 \mathrm{mS} / \mathrm{cm}$ and $<250 \mathrm{cfu} / \mathrm{mL}$ bacteria. The parameters for defining subclinically mastitic milk are absence of clinical signs, CMT positive, $\mathrm{SCC} \geq 200 \times 10^{3}$ cells $/ \mathrm{mL}, \mathrm{EC}>3.7 \mathrm{mS} / \mathrm{cm}$ and $>250 \mathrm{cfu} / \mathrm{mL}$ bacteria. Similarly, clinical mastitic milk was defined as milk having presence of clinical signs, CMT positive, $\mathrm{SCC} \geq 200 \times 10^{3}$ cells $/ \mathrm{mL}, \mathrm{EC}>3.7 \mathrm{mS} / \mathrm{cm}$ and $\mathrm{BC}>$ $250 \mathrm{cfu} / \mathrm{mL}$.
\end{abstract}

Key words: Somatic cell count, electrical conductivity, bacterial count, buffalo milk.

\section{Introduction}

The economic losses of mastitis due to severe drop of milk production, potential health risks for other animals and human beings, increased cost of treatment and culling processes are tremendous [1]. In addition to economic losses to the farmers, an effective control of mastitis is also important from the consumer's and processor's point of view, because the milk from affected animals may harbor organisms potentially pathogenic to humans and the processing of such milk

Corresponding author: Ishwari Prasad Dhakal, professor, research field: mastitis in water buffaloes. results in substandard fermented products [2]. Milk and milk products play vital role in human nutrition but they are also an ideal medium for growth and transmission of various pathogens.

Buffalo milk contains less water, more total solids, more fat, slightly more lactose and more protein than cow's milk [3]. It seems thicker than cow's milk because it contains more than $16 \%$ to $18 \%$ of the total solids compared with $12 \%$ to $14 \%$ per cow's milk [4]. A high somatic cell count (SCC) affects milk quality and cheese making resulting in a reduction in cheese yield and quality [5]. Higher SCC in buffalo milk causes a cheese softer and more brittle, which may be 
associated with an increase in moisture content. With a high SCC, buffalo milk has an alkaline $\mathrm{pH}$ and therefore, the rennetting time increases many folds. High SCC does not support growth of starter organisms thereby making it unfit for preparing fermented products [6].

The mastitis related measures such as California mastitis test (CMT), SCC, electrical conductivity (EC) and bacterial findings are needed for defining the buffalo milk. The requirement to define mastitis is to use at least two parameters describing the causative agents and the second parameter describing the inflammation. Studies on the occurrence of mastitis in buffaloes have been based on different tests and parameters, however, with unclear criteria for defining normal and mastitic milk, the results are difficult to interpret in buffaloes. So far normal threshold value of somatic cells and the cut-off value of EC in buffalo milk have not been evaluated.

The present study was designed to ascertain the epidemiological and bacteriological analyses of buffalo mastitis in Chitwan District of Nepal, characterize normal, subclinical and clinical mastitic milk using the possible parameters expressing hygienic quality of buffalo milk. In addition, the study was performed to define the threshold values of the CMT, SCC, EC and bacteriological counts in the milk, and to develop the diagnostic criteria for classification of milk from buffaloes.

\section{Materials and Methods}

\subsection{Animals}

Milk samples from 355 Murrah cross buffaloes located at Chitwan District, Nepal were examined. The total samplings included 428 quarter foremilk samples of clinically normal and 401 quarters from clinically affected buffaloes with mastitis. This experiment was conducted during 2003 to 2005 for three years. Approximately $10 \mathrm{~mL}$ of foremilk was collected from each quarter in two different test tubes according to the standard aseptic collection procedure outlined below. The first sample was processed sterilely for microbiological analysis and the second was tested for $\mathrm{pH}, \mathrm{CMT}$ and $\mathrm{EC}$ on site just after collection. At first, the hand of the milker was washed with weak iodine solution (Betadine ${ }^{\circledR}$ ) and air dried. The dirt was removed from the teats and udder with water by sterilized hands. The teat end was disinfected with cotton soaked in $70 \%$ ethyl alcohol. The first few streams of foremilk were discarded. Samples for analysis were then collected into sterilized test tubes. Samples for microbiological testing were held on ice until delivery to the laboratory within $15-30 \mathrm{~min}$ of collection. Samples were kept at room temperature before streaking onto culture plates in the laboratory. After microbiological sampling, the remaining milk was used for the SCC.

\subsection{Analysis of Rainfall and Temperature Records}

Temperature and rainfall records from 2002 to 2005 were collected from Bharatpur Municipality of Chitwan District, Nepal [7]. The maximum and minimum temperature of different months was recorded and the mean temperature for all the months of the four years was calculated. The maximum rainfall of the month was noted for each month of every year. Then the mean maximum rainfall for particular months was calculated from the values of the same month over four years. Temperature was measured in ${ }^{\circ} \mathrm{C}$ and rainfall was measured in millimeters $(\mathrm{mm})$.

\subsection{Isolation of Bacteria and Bacterial Count (BC)}

One hundred microlitres $(\mu \mathrm{L})$ of milk from each quarter was streaked onto MacConkey and 5\% ovine blood agar plates for bacterial culture and isolation. The colonies were counted after $48 \mathrm{~h}$ of incubation at $37^{\circ} \mathrm{C}$. Pure colonies from the respective plates were identified on the basis of Gram's stain, morphological findings, colony characteristics and biochemical tests [8].

\subsection{CMT}

The CMT was conducted at the farm during the 
evening milking time in the case of clinically normal buffaloes. However, the CMT was performed at Veterinary Teaching Hospital of Agriculture and Forestry University (AFU) during morning milking time in the case of clinically affected buffaloes.

The CMT method was carried out according to the method [9]. Equal volumes of milk and testing solution containing 3\% sodium lauryl sulfate and bromocresol purple $(1: 10,000)$ were mixed on a test plate with four quarter wells. The formation of viscous gel was evaluated as the plate was rotated gently. According to the changes of color and degree in the formation of gel, the result was interpreted as negative, trace, $1+, 2+$ and $3+[10]$.

\subsection{SCC}

The SCC and differential leucocyte counts were determined by Prescott and Breed method [10]. Milk was mixed thoroughly before testing. Ten microlitres $(\mu \mathrm{L})$ of milk from each quarter was spread over $1 \mathrm{~cm}^{2}$ marked square area on a glass slide. The milk film was left at room temperature until dry. The slide was then fixed in methanol for $5 \mathrm{~min}$, dried, held in the Newman-Lampert stain for $2 \mathrm{~min}$, dried at room temperature, and then washed in tap water three times and distilled water two times before a final drying at room temperature [7].

Somatic cells were counted under 1,000× magnification using oil immersion, and were calculated as follows: since $0.01 \mathrm{~mL}$ of milk was spread over $1 \mathrm{~cm}^{2}$, the possible number of fields which could be counted in $1 \mathrm{~cm}^{2}$ was 4,000 . Milk volume represented by each field was $1 / 100 \times 1 / 4,000=1 / 400,000$. Hence, microscopic factor (MF) was 400,000. The total number of fields counted was 50 . The working factor (WF) was $400,000 / 50=8,000$. The $\mathrm{SCC} / \mathrm{mL}=8,000 \times$ the number of cells counted [7].

\section{$2.6 E C$}

A manual digital mastitis detector (Milk checker N4 Oriental Instruments Ltd, Tokyo, Japan) was used for measurement of EC in milk. EC in milk was expressed as millisiemens per centimeter $(\mathrm{mS} / \mathrm{cm})$ at $25^{\circ} \mathrm{C}$. Absolute EC score was defined as the reading obtained directly from the EC meter and differential EC score was the difference between highest and lowest absolute EC score for the four quarters of each animal [11].

\subsection{Statistical Analysis}

CMT scores and mean SCC were analyzed using the Student's t-test. Interquarter comparisons of clinically normal and subclinical mastitic buffaloes were analysed using $\chi^{2}$ test.

Receiver operating characteristic (ROC) curve analyses were performed using Med Calc software, version 8.1.0.0 (Med Calc Software, Mariakerke, Belgium), which uses the method [12]. Data were compared statistically by using the Student's $t$-test.

ROC curve is a mathematical tool for assessing the usefulness of a diagnostic test at different cut off scores. In essence, it evaluates the diagnostic performance of a test, or the ability of a test to discriminate diseased cases from normal cases. ROC curve is a graph that plots the true positive rate in function of the false positive rate at different cut-off points. ROC curves plot the number of true positives (represented as sensitivity) versus the number of false positives (represented as: 1-specificity).

Positive predictive value (probability that the disease is present when the test is positive) and negative predictive value (probability that the disease is not present) were also examined.

\section{Results}

\subsection{Comparison of Clinical Mastitis}

The maximum number of cases of clinical mastitis was observed in the month of July (16\%) followed by June (12.2\%) and August (13.5\%). Results showed that $37.3 \%$ of buffaloes had clinical mastitis during the summer season followed by the autumn season (31.7\%). The months from June to August have the 
highest rainfall in Chitwan District, when the average temperature was $30^{\circ} \mathrm{C}$ (Fig. 1).

In clinical mastitis, coagulase negative Staphylococcus (CNS) (36\%) and coliforms (11\%) were the most commonly isolated pathogens (Fig. 2). The CNS, such as S. epidermidis (8.9\%) was detected. Micrococcus spp., Clostridium spp., Bacillus spp., Escherichia coli and Klebsiella spp. were other environmental pathogens isolated from quarters with clinical mastitis.

\subsection{CMT and $p H$}

Out of 188 quarter samples tested, 9\% had CMT positive scores in normal buffaloes (Fig. 3). CMT scores in the foremilk revealed $6 \%$ of the trace reactions in the quarter milk samples. Nearly $85 \%$ quarters had CMT negative scores.

Mean values of $\mathrm{pH}$ were highly significant $(p<$ 0.01 ) for CMT scores $2+$ and $3+$ groups compared with normal groups (Fig. 3). The normal $\mathrm{pH}$ of buffalo milk was $\mathrm{pH} 6.75 \pm 0.14$ at $25^{\circ} \mathrm{C}$ ranging from 6.39 to 7.08. The $\mathrm{pH}$ of subclinical mastitic and clinical mastitic milk was $6.85 \pm 0.14$ and $6.88 \pm 0.24$, respectively.

The SCC in subclinical and clinical mastitis was significantly higher $(p<0.01)$ than normal milk. Mean SCC in normal, subclinical and clinical mastitic milk was $176\left(30\right.$ to $800 \times 10^{3}$ cells $\left./ \mathrm{mL}\right), 958$ (300 to $6,500 \times 10^{3}$ cells $\left./ \mathrm{mL}\right)$ and $6,806 \times 10^{3}$ cells $/ \mathrm{mL}(250$ to $27,950 \times 10^{3}$ cells $/ \mathrm{mL}$ ), respectively (Fig. 4 ).

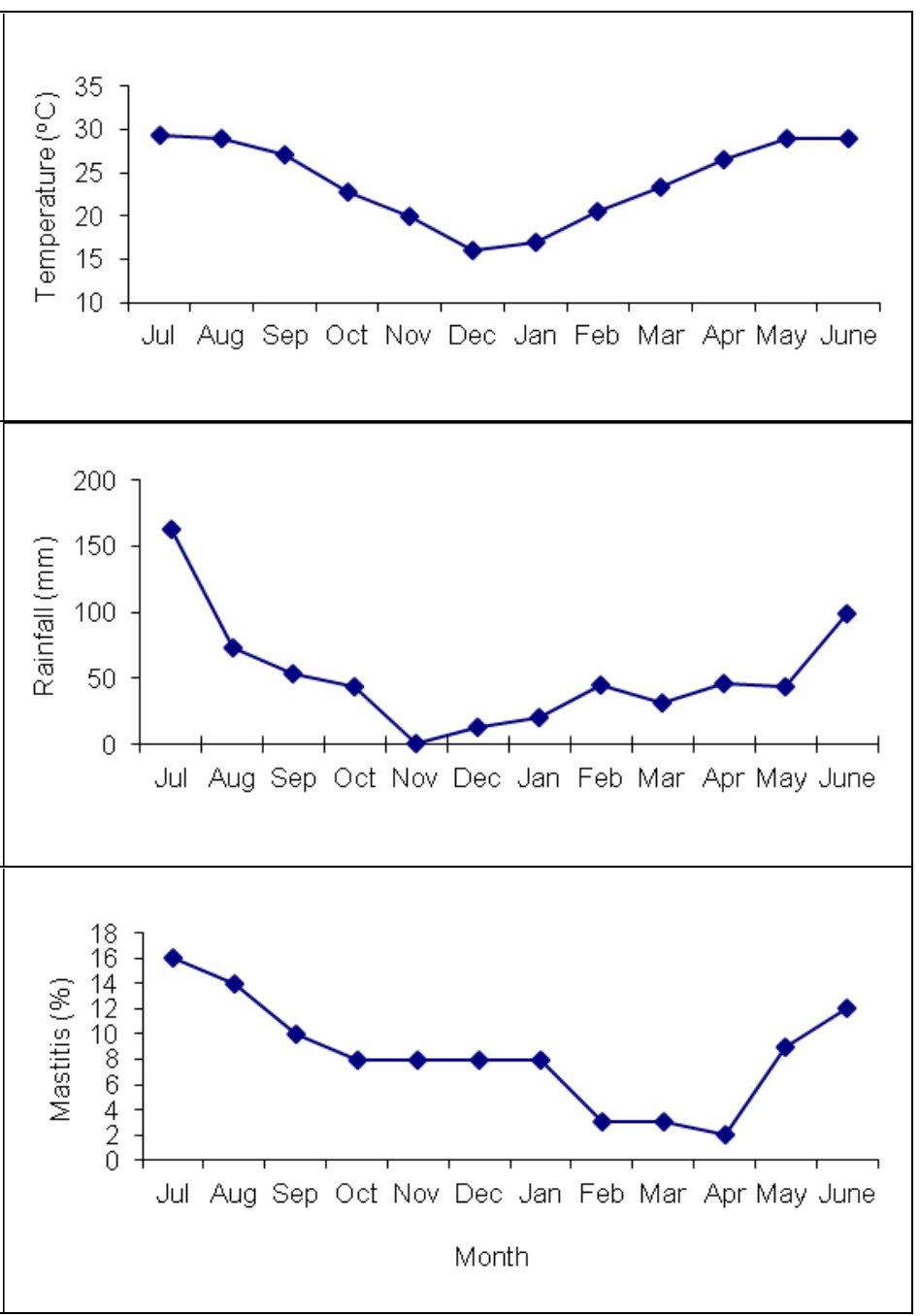

Fig. 1 Comparison of clinical mastitis in buffaloes with mean temperature and rainfall for four years. Data for temperature and rainfall were from Bharatpur Municipality, Chitwan District, Nepal. 


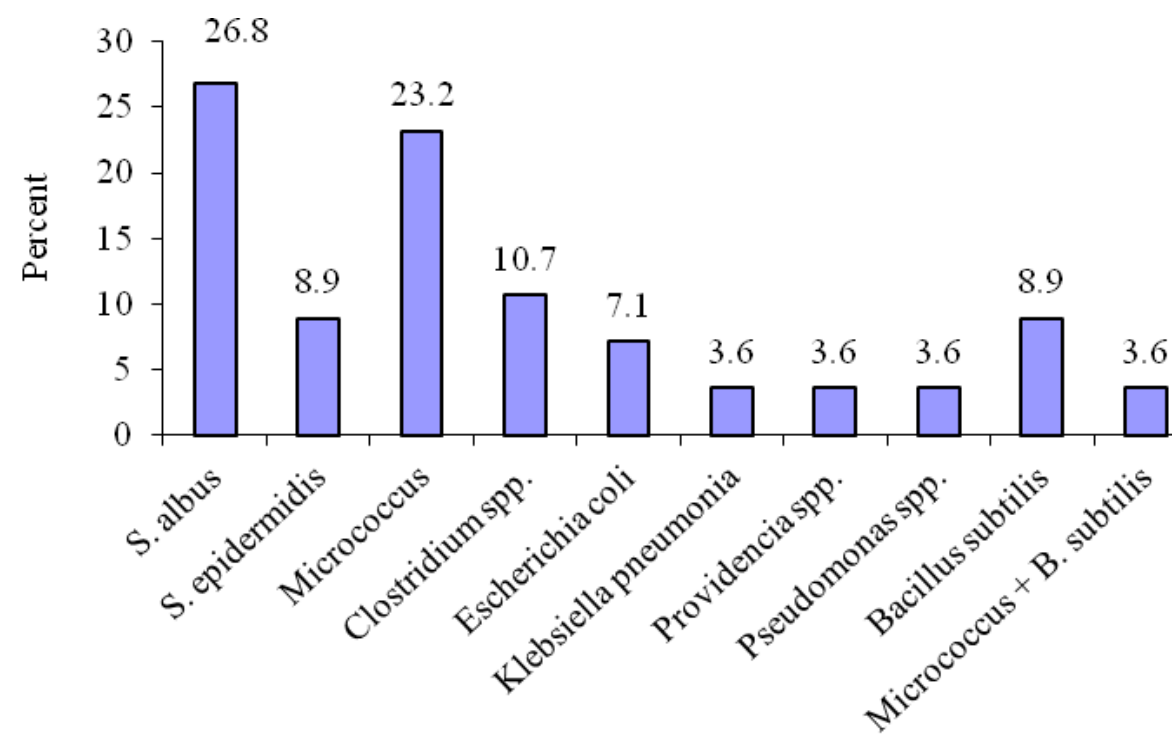

Pathogens

Fig. 2 Occurrence of microorganism in $\mathbf{5 6}$ isolates from the quarter milk of buffaloes with clinical mastitis.

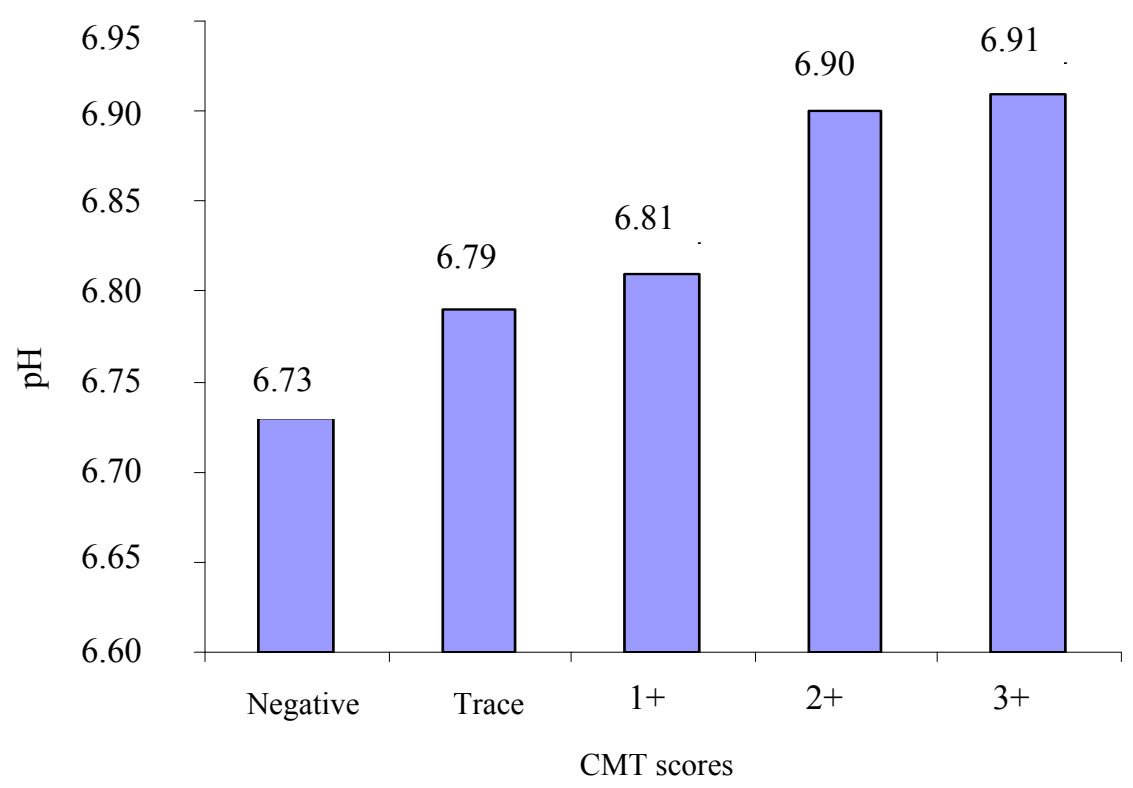

Fig. 3 Percentage distribution and relationship of California mastitis test (CMT) scores and mean pH of milk in 188 clinically normal buffaloes.

\subsection{Relationship between EC and SCC}

The cut-off score found by ROC curve analysis is the value corresponding with the highest accuracy. However, when a test is used for the purpose of screening, a cut-off value with a higher sensitivity may be selected; whereas, when a test is used to confirm a disease, a higher specificity may be required.

If the animals are to be screened on the basis of EC scores of milk false positive animals should be ruled 
out with further tests. Both positive likelihood ratio (LR) and negative LR are significantly different from one, which confirms the relationship of EC and mastitis.

Since the area under the ROC curve is significantly different from 0.5 (with $p<0.001$, but not for subclinical mastitis), there is a higher probability that a randomly selected mastitic animal will have greater EC value than a randomly selected normal animal.

As shown in Table 1, ROC analysis revealed that the best trade-off between sensitivity and specificity for diagnosing mastitis in buffalo from EC score occurred at the cut-off value of 3.7 (3.9 for clinical). The cut-off score 2.1 was required for $100 \%$ sensitivity, and 5.2 was required for $100 \%$ specificity in all cases, which would severely affect diagnostic accuracy (specificity and sensitivity) of the test. ROC curve generated from the data is shown in Figs. 5 and 6.

In normal milk, EC values and $\mathrm{SCC} / \mathrm{mL}$ are positively correlated $(r=0.05)$. The milk EC was found higher when $\mathrm{SCC} / \mathrm{mL}$ of milk was increased (Fig. 7). There was a relationship between individual quarter milk conductivity and occurrence of mastitis. The EC values increased in association with increasing SCC, bacteria in the milk and flakes or clots in the milk of buffaloes.

\subsection{Classification of Buffalo Milk}

Normal milk was defined as having SCC $\leq 200 \times$ $10^{3}$ cells $/ \mathrm{mL}$, CMT negative, $\mathrm{BC}<250 \mathrm{cfu} / \mathrm{mL}$ and the absence of clinical signs (Table 2).

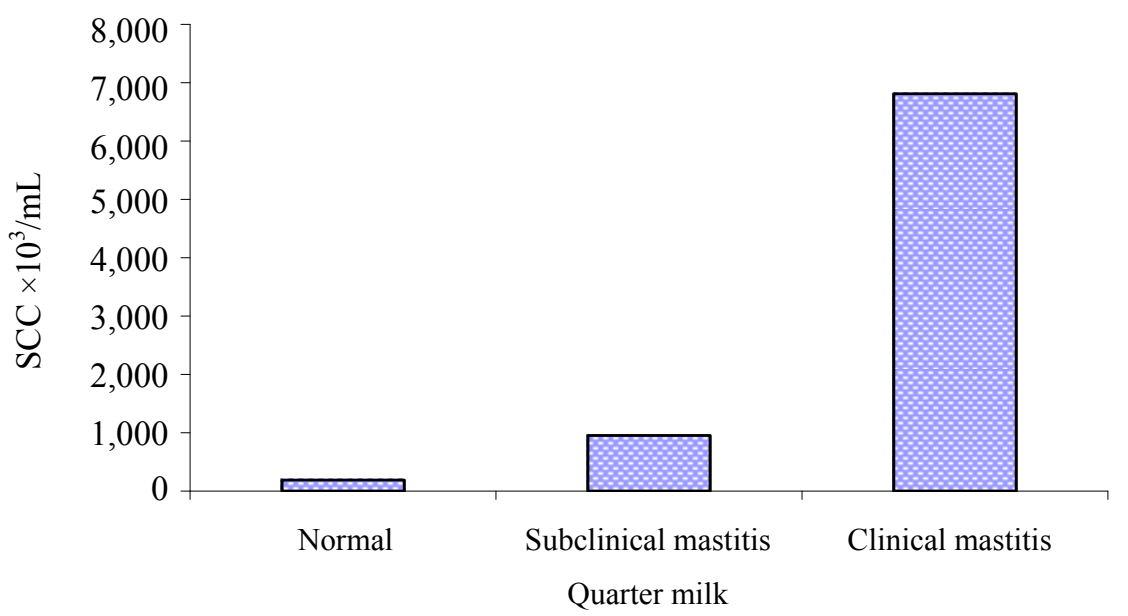

Fig. 4 Comparison of mean somatic cell count (SCC) $\times 10^{3} / \mathrm{mL}$ of milk in normal, subclinical and clinical mastitis.

Table 1 Sensitivity, specificity, likelihood ratio (LR) and predictive values of electrical conductivity (EC) test for mastitis detection.

\begin{tabular}{llllllll}
\hline Category of mastitic milk & Cut-off score & $\begin{array}{l}\text { Sensitivity } \\
(95 \% \text { C.I. })\end{array}$ & $\begin{array}{l}\text { Specificity } \\
(95 \% \text { C.I. })\end{array}$ & + LR & - LR & PPV & NPV \\
\hline Sub clinical & 3.7 & $\begin{array}{l}73.3 \\
(44.9-92.0)\end{array}$ & $\begin{array}{l}59.2 \\
(50.6-67.3)\end{array}$ & 1.8 & 0.5 & 16 & 95.5 \\
Clinical & 3.9 & $\begin{array}{l}85.7 \\
(63.6-96.8)\end{array}$ & $\begin{array}{l}75.4 \\
(67.4-82.2)\end{array}$ & 3.5 & 0.2 & 34 & 97.3 \\
\hline
\end{tabular}

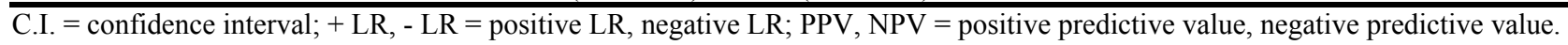




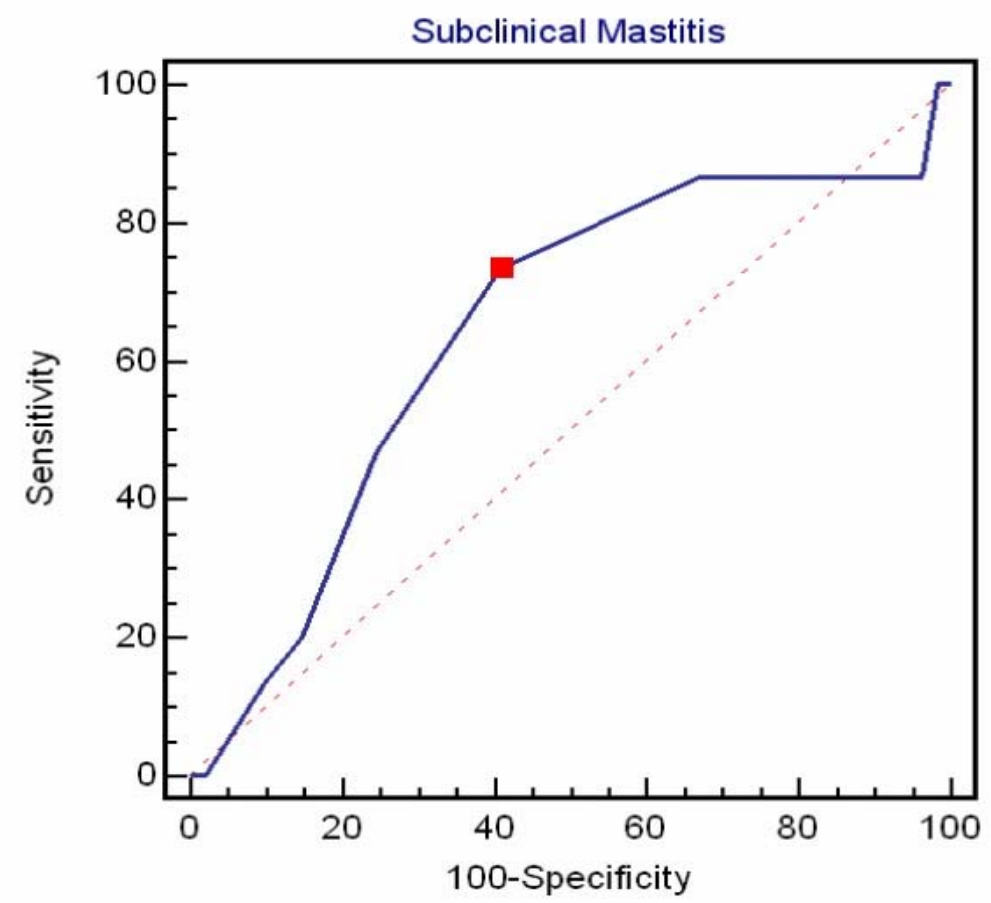

Fig. 5 Receiver operating characteristic (ROC) curve for subclinical mastitis indicating sensitivity of electrical conductivity (EC) (\% true positive) versus 1 -specificity (\% false positive).

Values for these two variables at different cut-off scores would fall on the diagonal indicated by the dashed line in curves. Ideal cut-off value is the point in the curve that is located closest to the upper left hand corner.

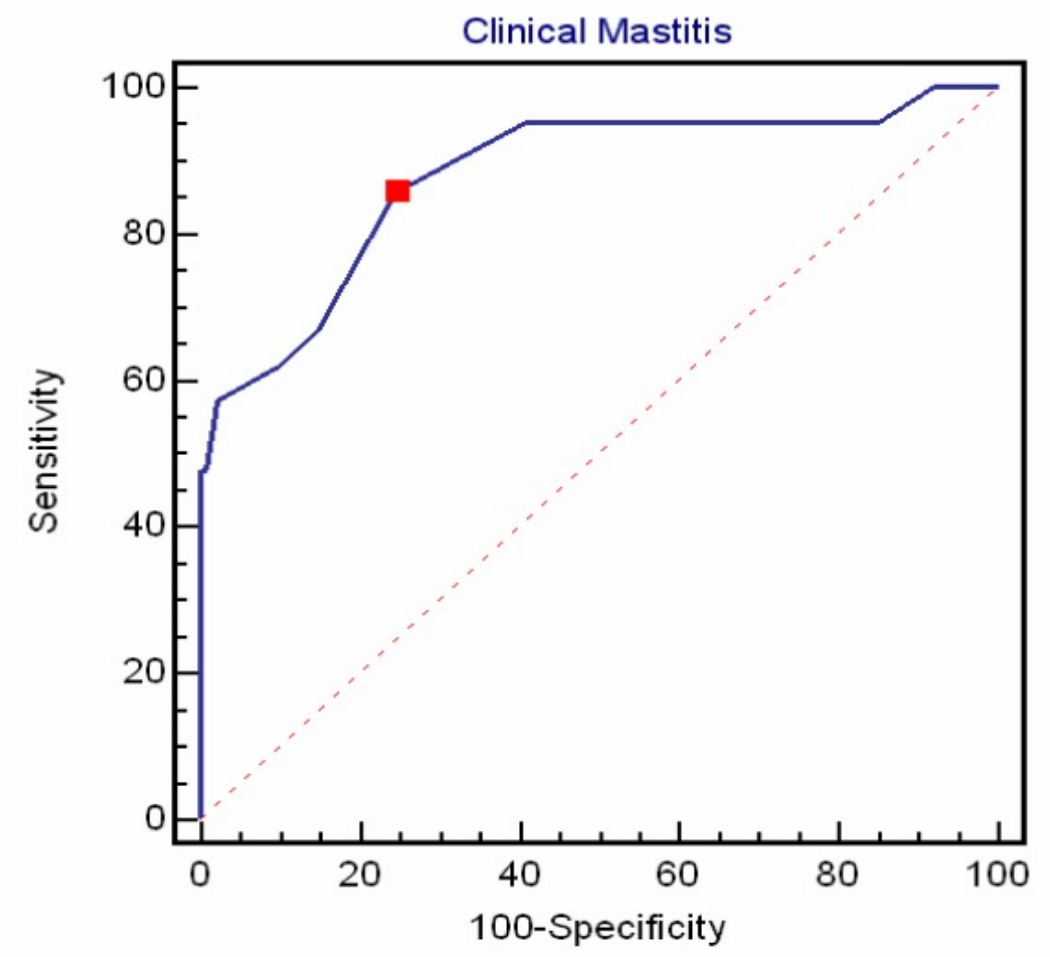

Fig. 6 ROC curve for clinical mastitis indicating sensitivity of EC (\% true positive) versus 1-specificity (\% false positive). Values for these two variables at different cutoff scores would fall on the diagonal indicated by the dashed line in curves. Ideal cutoff value is the point in the curve that is located closest to the upper left hand corner. 


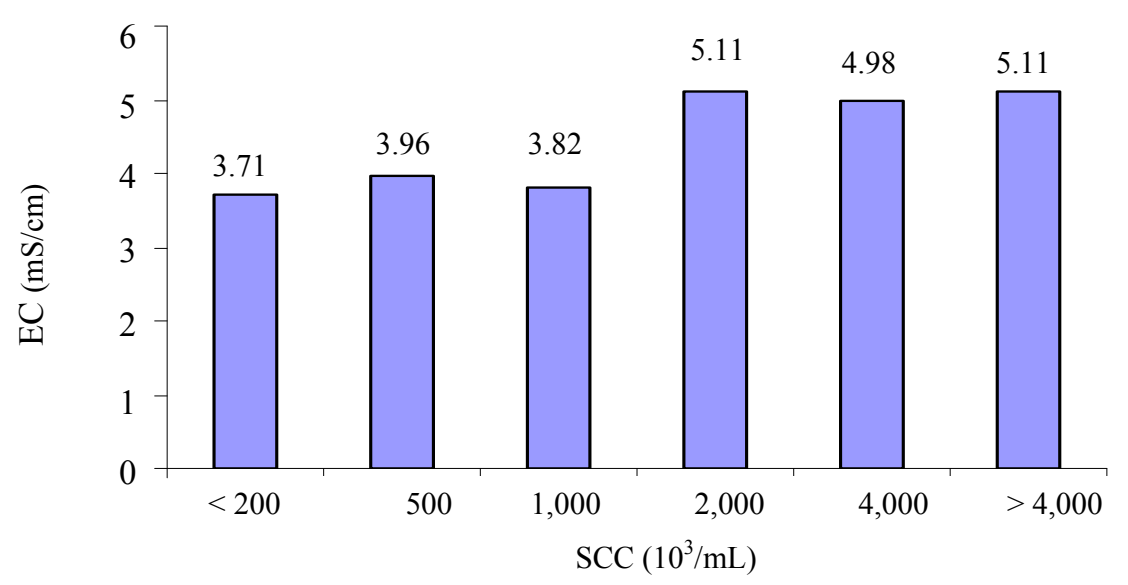

Fig. 7 Relationship between SCC and EC in 188 quarter milk of buffaloes.

Table 2 Classification of normal, subclinical and clinical mastitic milk using five parameters.

\begin{tabular}{|c|c|c|c|c|c|}
\hline Classification & Parameters $\mathrm{SCC} / \mathrm{mL}$ & CMT & $\begin{array}{l}\begin{array}{l}\mathrm{EC} \\
(\mathrm{mS} / \mathrm{cm})\end{array} \\
\end{array}$ & $\begin{array}{l}\mathrm{BC} \\
(\mathrm{cfu} / \mathrm{mL})\end{array}$ & Clinical signs \\
\hline Normal & $<200,000$ & Negative & 3.7 & $<250$ & Absent \\
\hline Subclinical & $>200,000$ & Positive & $>3.7$ & $>250$ & Absent \\
\hline Clinical & $>200,000$ & Positive & $>3.7$ & $>250$ & Present \\
\hline
\end{tabular}

\section{Discussion}

\subsection{Bacteriological Analysis}

The highest incidence of clinical mastitis was found in the summer season in Chitwan District, Nepal and the most frequently isolated bacteria were CNS (36\%) and coliforms (11\%). This finding was in consistent with that of Moroni et al. [12] and Guccione et al. [13], who reported that CNS were the most common pathogen isolated in dairy buffalo milk. The greatest number of clinical cases of mastitis was observed in the month of July (16\%). The reason for the high incidence of clinical mastitis during this month may be associated with not only heat stress but poor hygienic conditions found in buffaloes during high temperature and humidity in the summer season. In addition, this period is conducive for proliferation and easy access of pathogenic organism into the mammary gland of buffaloes for precipitating the disease [14].

Minor pathogens and coliforms are often isolated from the skin of the udder due to contamination with soil and feces. The challenges in buffalo farming include poor hygiene in the environment, contaminated housing, inadequate milking hygiene, hand milking of wet teats, organic bedding materials (chopped straw), calving and milking in the same shed, and calf suckling.

Coagulase positive Staphylococcus spp. was primary pathogen or major pathogen where CNS and micrococcus were secondary pathogen or minor pathogens. The reliability of bacteriological diagnosis of primary pathogen infection was supported by indirect evidences such as marked elevation of SCC and clinical symptoms but these were less frequent features of secondary pathogen infection. It is well known that micrococci was capable of producing mild degree of udder irritation, slight leukocytosis and reducing milk yield. It has not been reported that their presence may reduce infection rate of primary pathogen. Further study is required to determine the real significance of micrococci in mastitis control in buffaloes.

Staphylococci are the most problematic and significant mastitis pathogen. Faulty milking 
encourages the transfer of bacteria into the teat cistern [15]. Staphylococci typically colonize the broken skin and can enter the udder through abrasions of the teat end, increasing the risk of Staphylococci colonization at the teat end and subsequent transfer into the udder. Characteristic findings in buffalo mastitis in Chitwan, Nepal revealed that clinical mastitis was influenced by season, parity and stage of lactation.

\subsection{CMT, $p H$ and SCC}

It is generally accepted that mastitis causes a rise in milk $\mathrm{pH}$. This is primarily due to leakage of blood bicarbonate into milk following damage to mammary epithelium. The increasing $\mathrm{pH}$ decreases significantly the activity of enzymes used to clot the milk, thus having implications in the manufacturing potential of milk for dairy products [16]. The average $\mathrm{pH}$ of normal buffalo milk was 6.75 , and was similar to that reported [17] in Sri Lanka showing 6.5 (6.1 to 7.0). There was a positive relationship between milk $\mathrm{pH}$ and EC in normal, subclinical and clinical mastitic milk. Lactose is the main determinant for $\mathrm{pH}$ and is the most important osmotic component of the milk [18]. If lactose concentration falls in the udder during mastitis then the sodium and chloride level increases ten times to maintain the osmotic pressure of the milk [19].

In clinically affected buffaloes, $45 \%$ of the quarters were found CMT positive. This indicates that the greater number of somatic cells was migrated in the milk. In this study, $27 \%$ of the quarters having CMT positive scores were found bacteriologically negative indicating nonspecific clinical mastitis, i.e., latent mastitis where $\mathrm{SCC}$ value was also increased.

The mean SCC in different categories of CMT in buffalo milk revealed that a negative score for normal milk had $134 \times 10^{3}$ cells $/ \mathrm{mL}$. In the present study, $9.57 \%$ of the quarters had CMT positive scores in healthy buffaloes, which is similar to the findings [20, 21]. In contrary to the present findings, Patil et al. [22] reported a higher prevalence rate of CMT positive quarters, i.e., $28.3 \%$. Such variations in CMT result may be due to varied managemental and hygienic practices in different farms under village conditions. Somatic cell counting has become one of the recommended tests in bulk milk analysis as an indicator of mastitis because a major factor responsible for a high SCC is udder infection due to pathogenic organisms [23].

The study of SCC at the buffalo farms in Chitwan and Hissar gave an upper limit of $151 \times 10^{3}$ cells $/ \mathrm{mL}$ in the buffalo milk being based on the mean $+2 \mathrm{SD}$ ( $\mathrm{SD}=$ standard deviation) of a total of SCC [7]. Total SCC includes leucocytes (such as neutrophils, lymphocytes and macrophages) and epithelial cells. Therefore, the upper limit was defined to be $200 \times 10^{3}$ cells $/ \mathrm{mL}$ for practical diagnostic purpose. In contrast to the present finding, lower average SCC such as 136 $\times 10^{3}$ cells $/ \mathrm{mL}$ in July to August, $108 \times 10^{3}$ cells $/ \mathrm{mL}$ in May to June and $76 \times 10^{3}$ cells $/ \mathrm{mL}$ in December to January, was reported in Indian Murrah buffaloes [24]. However, in Sri Lanka, it is reported that total SCC in normal buffalo milk varied from $50 \times 10^{3}$ cells $/ \mathrm{mL}$ to $375 \times 10^{3}$ cells $/ \mathrm{mL}$ of milk [25]. Possible reasons for higher SCC in normal buffaloes may be due to various factors such as compositional changes of the milk, environmental stress and the quarter udder capacity of buffaloes, as found in dairy cows [12]. This threshold level of $200 \times 10^{3}$ cells $/ \mathrm{mL}$ of milk for the SCC may be the standard value for detection of subclinical mastitis in buffaloes in the future.

The SCC in the quarter milk of clinically normal buffaloes in Rampur, Nepal and surrounding area was $176 \pm 132 \times 10^{3}$ cells $/ \mathrm{mL}$. The SCC reported for normal buffaloes in Brazil was $>200 \times 10^{3}$ cells $/ \mathrm{mL}$, i.e., $63.6 \pm 185.7 \times 10^{3}$ cells $/ \mathrm{mL}$ [26]. The $\mathrm{SCC}$ of healthy buffalo milk was $100 \times 10^{3}$ cells $/ \mathrm{mL}(76-135$ $\times 10^{3}$ cells $/ \mathrm{mL}$ ) in India [24]. It is known that type of breed, husbandry, age, parity, injury of the udder and stage of lactation affects the SCC in milk [24]. The SCC of normal milk of Murrah buffalo in Chitwan, Nepal and Hissar, India was $<200 \times 10^{3}$ cells $/ \mathrm{mL}$ [7]. 
The SCC observed in this study was lower than those of crossbred cows under similar set of management condition; a finding may be due to a larger udder capacity, leading to less stress of the udder in buffaloes compared to those of the cattle [27].

\subsection{EC Values}

EC values in normal, subclinical and clinical mastitic milk were found to be 3.76, 3.93 and 5.34 $\mathrm{mS} / \mathrm{cm}$, respectively. The best trade-off between sensitivity and specificity for diagnosing mastitis in buffalo from EC score was found at the cut-off value of $3.7 \mathrm{mS} / \mathrm{cm}$.

Mastitis can lead to damage of mammary epithelium, which increases the release of electrolytes such as sodium and chloride. Increases in the sodium and chloride content of mastitic milk have also been correlated with an increase in EC [28]. The EC value in clinically normal buffalo was $3.72 \mathrm{mS} / \mathrm{cm}$. Silva et al. [17] detected the EC in buffalo milk and reported a slightly higher EC value of $3.86 \mathrm{mS} / \mathrm{cm}$ in normal milk and $4.46 \mathrm{mS} / \mathrm{cm}$ in subclinical mastitic milk. In contrary to this, the variation of EC in normal milk of cows was from 4 to 5.5 , and the variation of the quarters within the same cow with normal milk was $0.5 \mathrm{mS} / \mathrm{cm}$ [29].

The EC score in buffalo milk was comparatively lower than that of cow milk. This may be associated with higher fat content (7.5\%) in buffalo milk composition as suggested previously, i.e., milk fat concentration increases, EC decreases [30]. Fat is a poor conductor and fat globules form a physical hindrance to migrating ions and reduce the volume of conducting medium [31]. Increase in the sodium and chloride content of mastitic milk has also been correlated with an increase in EC [32].

The EC values increased in association with increasing SCC, bacteria in the milk and flakes or clots in the milk of buffaloes. Milk infected with coliforms has a significantly higher $(p<0.05)$ EC than that of CNS. It is reported that the presence of bacteria, changes in SCC and clots in milk are the common factors resulting in changes in EC of milk [33]. The correlation between $\mathrm{SCC}$ and $\mathrm{EC}$ was $r=0.53$ in buffalo mastitic milk. Similar value $(r=0.4)$ in cows was reported [34]. Although an increase in the EC of milk at the quarter level or animal level indicates subclinical and clinical mastitis, the correlation between EC and SCC was not very high [35]. There is little effect from the EC in quarters free of infection [34] and EC may have an advantage of defining infection status. Despite the effect of several factors on the EC of milk, only intramammary infection is likely to influence EC of individual quarters [36].

Acceptable levels of sensitivity and specificity of tests will depend upon the purpose of the test, the setting of testing (e.g., for general population or for a specific subgroup at risk for the condition), the prevalence of the condition in the group being tested, alternative methods of assessment, and costs and benefits of testing. The cut-off score found by ROC curve analysis is the value corresponding with the highest accuracy. However, when a test is used for the purpose of screening, a cut-off value with a higher sensitivity may be selected; whereas, when a test is used to confirm a disease, a higher specificity may be required [37]. Changing the cut-offs between positive and negative test results will affect the test characteristics [11]. To the best of our knowledge, this is the first report describing cut-off value of EC in buffalo milk. Based on the samples studied, the specificity of the EC test was rather low at the cut-off value for highest accuracy, especially for subclinical mastitis. The false positives are less serious than false negatives in terms of permanent udder damage and economic losses. Therefore, if the animals are to be screened on the basis of EC scores of milk false positive animals should be ruled out with further tests. Both positive LR and negative LR are significantly different from one, which confirms the relationship of EC and mastitis. Since the area under the ROC curve 
is significantly different from 0.5 (with $p<0.001$, but not for subclinical mastitis), there is a higher probability that a randomly selected mastitic animal will have greater EC value than a randomly selected normal animal.

Our findings revealed that EC is a suitable test for the detection of mastitis in general, rather than representing different types of mastitis. Use of EC is gaining recognition as a practical method for routine monitoring of individual quarters [38].

\subsection{Classification of Buffalo Milk}

Subclinical mastitis was defined as milk having SCC $\geq 200 \times 10^{3}$ cells $/ \mathrm{mL}$, CMT positive, $\mathrm{BC}>250$ $\mathrm{cfu} / \mathrm{mL}$ and the absence of clinical signs. Clinical mastitis was defined as milk having $\mathrm{SCC} \geq 200 \times 10^{3}$ cells $/ \mathrm{mL}$, CMT positive, BC $>250 \mathrm{cfu} / \mathrm{mL}$ and the presence of clinical signs.

This study categorizes buffalo milk into normal, subclinical and clinical mastitis using five parameters. In normal milk, the SCC was $<200 \times 10^{3}$ cells $/ \mathrm{mL}$ and pathogenic bacteria were absent. In subclinical mastitis, $\mathrm{SCC} / \mathrm{mL}$ was $\geq 200 \times 10^{3}$ cells $/ \mathrm{mL}$ and bacteria were cultured from the samples. In clinical mastitis, $\mathrm{SCC} / \mathrm{mL}$ was $\geq 200 \times 10^{3}$ cells $/ \mathrm{mL}, \mathrm{BC}>$ $250 \mathrm{cfu} / \mathrm{mL}$ and presence of clinical signs.

On quarter basis, $16 \%$ and $11 \%$ of the foremilk samples in buffaloes were having subclinical and clinical mastitis respectively using five parameters, i.e., SCC, CMT, EC, BC and clinical signs. The prevalence of subclinical mastitis in Murrah buffaloes was $16 \%$. However, higher prevalence $(18.8 \%)$ of subclinical mastitis in the lactating buffaloes in the state of Sao Paulo, Brazil was reported [39]. A lower prevalence of subclinical mastitis (11.7\%) was reported in Iraq [40]. The prevalence of subclinical mastitis was highest (31.3\%) during the first calving and declined in successive calving [41]. Higher prevalence of heifer mastitis was obtained in buffaloes with poor housing which provides an ideal environment for microbial growth and high density of animals makes heifers more susceptible to environmental pathogens. The prevalence of clinical mastitis in this study was $11 \%$. However, slightly higher incidence of clinical mastitis (12.5\%) in Murrah buffaloes was reported in India [14].

Single cell count threshold does not reflect subclinical cases because of the elevation of the cell count in non-infectious mastitis. Thus, subclinical mastitis is diagnosed on the basis of cell counts and bacteriological findings. The diagnosis of subclinical mastitis only by bacteriological examination has certain limitations of not showing the effect of inflammatory reactions. Single bacteriological examination is difficult to interpret and is not suitable for the diagnosis of the udder health in buffaloes. Similarly, EC values may not be suitable as a single detection system because this test has not reflected the bacteriological status of the individual quarters.

It is suggested that for diagnostic purposes of subclinical mastitis it may be adequate to analyze two parameters: one for inflammation and another for infection in order to get a more precise characterization of the udder. This study provides useful and practical information concerning the classification of buffalo milk, and can contribute to the effective control of mastitis and further mastitis research in buffalo.

\section{Conclusions}

The maximum number (16\%) of clinical cases of mastitis was observed in the month of July and lowest in the month of April (1.6\%). On quarter basis, 16\% of the foremilk samples in buffaloes were diagnosed as having subclinical mastitis and $11 \%$ were diagnosed as having clinical mastitis. The results of CMT scores and SCC showed the evidence that subclinical and clinical mastitic milk were having CMT positive scores $(+1 \sim+3)$ with $\geq 200 \times 10^{3}$ cells $/ \mathrm{mL}$. The mean $\mathrm{pH}$ of clinically normal buffalo milk was 6.75 and subclinical mastitic and clinical mastitic milk was 6.85 and 6.88 , respectively. 
Analysis of EC value in the milk revealed the cut-off values $3.7 \mathrm{mS} / \mathrm{cm}$. The CNS was the predominant organisms associated with subclinical mastitis, and CNS and coliforms in clinical mastitis. In this study, $9.5 \%$ of the quarters were having $\mathrm{BC}$ more than 250 $\mathrm{cfu} / \mathrm{mL}$. The proposed criteria for normal milk are absence of clinical signs, CMT negative, $\mathrm{SCC}<200 \times$ $10^{3}$ cells $/ \mathrm{mL}, \mathrm{EC}<3.7 \mathrm{mS} / \mathrm{cm}$ and $<250 \mathrm{cfu} / \mathrm{mL}$ bacteria. The parameters for defining subclinically mastitic milk are absence of clinical signs, CMT positive, $\mathrm{SCC} \geq 200 \times 10^{3}$ cells $/ \mathrm{mL}, \mathrm{EC}>3.7 \mathrm{mS} / \mathrm{cm}$ and $>250 \mathrm{cfu} / \mathrm{mL}$ bacteria. Similarly, clinical mastitic milk was defined as milk having presence of clinical signs, CMT positive, $\mathrm{SCC} \geq 200 \times 10^{3}$ cells $/ \mathrm{mL}, \mathrm{EC}>$ $3.7 \mathrm{mS} / \mathrm{cm}$ and $\mathrm{BC}>250 \mathrm{cfu} / \mathrm{mL}$.

\section{References}

[1] Dhakal, I. P., and Thapa, B. B. 2002. "Economic Impact of Clinical Mastitis in the Buffaloes in Nepal." Buffalo $J$. 2: 225-34.

[2] Bilal, M. Q., Iqbal, M. U., Mohammad, G., Avais, M., and Sajid, M. S. 2004. "Factors Affecting the Prevalence of Clinical Mastitis in Buffaloes around Faisalabad District (Pakistan)." Int. J. Agric. Biol. 6: 185-7.

[3] Sah, N. P. 1988. "Seasonal Variation of Certain Milk Constituents of Haryana Cows and Murrah Buffaloes at IAAS Livestock Farm, Rampur." Bull. Vet. Sci. \& Anim. Hosp. Nepal 16: 23-8.

[4] Xue, H., Frank, L. L., Zhang, L., and Guo, M. R. 2012. "Chemical Composition of Water Buffalo Milk and Its Low Fat Symbiotic Yogurt Development.” Functional Foods in Health and Disease 2 (4): 86-106.

[5] Piccinini, R., Miarelli, M., Ferri, B., Tripaldi, C., Belotti, M., Dapra, V., Orlandini, S., and Zecconi, A. 2006. "Relationship between Cellular and Whey Components in Buffal Milk.” J. Dairy Res. 14: 1-5.

[6] Schultz, L. H. 1977. "Somatic Cell Counting of Milk in Production Testing Program as a Mastitis Control Technique." J. Am. Vet. Med. Assoc. 170: 1244-6.

[7] Dhakal, I. P. 2006. "Normal Somatic Cell Count and Subclinical Mastitis in Murrah Buffaloes." J. Vet. Med. B 53: 81-6.

[8] Cowan, S. T., and Steel, K. J. 2004. Manual for the Identification of Medical Bacteria (3rd ed.), edited by Barrow, G. I., and Feltham, R. K. A. New York: Cambridge University Press.

[9] Schalm O. W., and Noorlander, D. O. 1957. "Experiments and Observations Leading to Development of the California Mastitis Test." J. Am. Vet. Med. Assoc. 130: 199-204.

[10] Schalm, O. W., Carroll, E. J., and Jain, N. C. 1971. "Number and Types of Somatic Cells in Normal and Mastitic Milk.” In Bovine Mastitis (1st ed.). Philadelphia: Lea and Febiger, 94-127.

[11] Musser, J. M. B., Anderson, K. L., Caballero, M., Amaya D., and Puga, J. M. 1998. "Evaluation of Hand Held Electrical Conductivity Meter for Detection of Subclinical Mastitis in Cattle." Am. J. Vet. Res. 59: 1087-91.

[12] Moroni, P., Rossi, C. S., Pisoni, G., Bronzo, V., Castiglioni, B., and Boettcher, P. J. 2006. "Relationship between Somatic Cell Count and Intramammary Infection in Buffaloes.” J. Dairy Sci. 89: 998-1003.

[13] Guccione, J., Perreten, V., Steiner, A., Thoman, A., Pesce, A., and Ciaramella, P. 2016. "Short Communication: Role of Streptococcus pluranimalium in Mediterranean Buffaloes (Bubalus bubalis) with Different Udder Health Status.” J. Dairy Sci. 99 (4): 2945-9.

[14] Taraphder, S., Tomar, S. S., and Gupta, A. K. 2006. "Incidence, Inheritance and Economics of Mastitis in an Organised Herd of Murrah Buffaloes." Indian J. Anim. Sci. 76: 838-42.

[15] Dhakal, I. P. 1997. "Drug Selection and Use on Clinical Mastitis in Buffaloes at Chitwan Valley of Nepal." Bubalus Bubalis 5: 56-70.

[16] Subedi, K., and Dhakal, I. P. 2002. "Clinical Mastitis in Different Breeds of Cattle and Buffaloes at Chitwan, Nepal.” J. Inst. Agric. Anim. Sci. 23: 65-9.

[17] Silva, I. D., Silva, K. F. S. T., Amboyala, A. P. N., Cooray, R., Perera, B. M. A. O., Siriwardene, J. D. S., Horadagoda, N. U., and Ibrahim, M. N. M. 1995. "Role of Buffalo in Rural Development in Asia." In Proceedings of a Regional Symposium, Perudenia, Sri Lanka, 403-14.

[18] Blowey, R., and Edmondson, P. 2010. "Structure of Teats and Udder and Mechanism of Milk Synthesis." In Mastitis Control in Dairy Herd: An Illustrated \& Practical Guide. United Kingdom: Farming Press, 16.

[19] Kitchen, B. 1981. "Review of the Progress of Dairy Science Bovine Mastitis: Milk Compositional Changes and Related Diagnostic Tests." J. Dairy Res. 48: 167-80.

[20] Praveen, K., Thakur, D. K., and Kumar, P. 2001. "Comparative Efficacy of Indirect Tests for the Detection of Mastitis in Buffaloes.” Indian Vet. J. 78: 801-3.

[21] Mandali, G. C., Patel, P. R., Dhami A. J., and Raval, S. K. 2002. "Calving Pattern and Periparturient Disorders in Buffaloes of Gujrat in Relation to Season and Meteriological Factors." Indian J. Vet. Med. 22: 15-20. 
[22] Patil, R. L., Prasanna, K. S., Sudhindra, V. B. S., and Honnappagol, S. S. 2005. "Epidemiology of Subclinical Mastitis in Buffaloes under Field Conditions of Bidar, Karnataka State, India." Buffalo Bull. 24: 91-7.

[23] Schallibaum, M. 2001. "Impact of SCC on the Quality of Fluid Milk and Cheese." In Proceedings of National Mastitis Council, Annual Meeting Proceedings, Arlington, $38-46$.

[24] Singh, M., and Ludri, R. S. 2001. "Somatic Cell Counts in Murrah Buffaloes (Bubalus bubalis) during Different Stages of Lactation, Parity and Season." Asian Aust. J. Anim. Sci. 14: 189-92.

[25] Silva, I. D., and Silva, K. F. S. T. 1994. "Total and Differential Cell Counts in Buffalo Milk.” Buffalo J. 2: 133-7.

[26] Munoz, M. C., Tonhati, H., Duarte, J., Oliveira, J., Berrocal, M. M., and Gamez, H. J. 2002. "Factors Affecting Somatic Cell Counts and Their Relations with Milk and Milk Constituent Yield in Buffaloes." J. Dairy Sci. 85: 2885-9.

[27] Harmon, R. J. 1994. "Physiology of Mastitis and Factors Affecting Somatic Cell Count.” J. Dairy Sci. 77: 2103-12.

[28] Vallejo, L. C., and Carreira, R. E. 1985. "Electric Conductivity of Milk Secretion Their Value for the Diagnosis of Bovine Mastitis." Vet. Argent. 17: 604-10.

[29] Thomus, C. S., Nimmervoll, H., Boije, C., Sjaunja, K. S., Lundeheim, N., and Ostensson, K. 2004. "Occurrence of Subclinical Mastitis in Buffaloes in Different Herd Sizes and Milking Management Systems." Buffalo J. 3: 289-306.

[30] Nielen, M., Deluyker, H., and Schukken, Y. H. 1992. "Electrical Conductivity of Milk, Measurement, Modifiers and Meta Analysis of Mastitis Detection Performance.” J. Dairy Sci. 75: 606-14.

[31] Prentice, J. H. 1962. "The Conductivity of Milk-The Effect of the Volume and Degree of Dispersion of the Fat.” J. Dairy Res. 29: 131-9.

[32] Wagner, T. N., and Stull, J. W. 1978. "Relation between
Mastitis Test Score, Mineral Composition of Milk and Blood Electrolyte Profiles in Holstein Cows." J. Dairy Sci. 61: 1755-9.

[33] Milner, P., Page, K. L., Walton, A. W., and Hillerton, J. E. 1996. "Detection of Clinical Mastitis by Changes in Electrical Conductivity of Foremilk before Visible Changes in Milk." J. Dairy Sci. 79: 83-6.

[34] Sheldrake, R. F., McGregor, G. D., and Hoare, R. J. T. 1983. "Somatic Cell Count, Electrical Conductivity and Serum Albumen Concentrations for Detecting Bovine Mastitis.” J. Dairy Sci. 66: 548-55.

[35] Hogeveen, H., Sampimon, O. C., Hanekamp, W. J. A., and Sol, J. 1998. "Monitoring Subclinical Intramammary Infection on a Low Bulk Milk Somatic Cell Count Farm." In Proceeding of 37th Meeting of the National Mastitis Council, Arlington, 117-26.

[36] Schultz, W. D. 1986. "Development in Mastitis Detection." In Proceedings of the 25th National Mastitis Council, Washington, 24-35.

[37] Hanley, J. A., and McNeil, B. J. 1983. "A Method of Comparing the Areas under Receiver Operating Characteristic Curves Derived from the Same Cases." Radiology 148: 839-43.

[38] Norberg, E., Hogeveen, H., Korsgaard, I. R., Friggens, N. C., Sloth, K. H., and Lovendahl, P. 2004. "Electrical Conductivity of Milk: Ability to Predict Mastitis Status." J. Dairy Sci. 87: 1099-107.

[39] Costa, E. O., Watanabe, E. T., Ribeiro, A. R., Garino, F., Houriti, A. M., and Baruselli, P. S. 2000. "Mastitis Bubaline: Etiologia, Indices de Mastitis Clinica e Subclinica." Napgama 1: 12-5.

[40] Rahman, H., Sambyal, D. S., and Baxi, K. K. 1983. "Incidence and Etiology of Subclinical Mastitis in Cows and Buffaloes in Punjab." J. Dairy Res. 20: 208-12.

[41] Dhakal, I. P., Neupane, M., and Nagahata, H. 2006. "Buffalo Milk Characteristics in Health and Disease." Anim. Sci. J. 79: 628-33. 